\title{
Abdominal mass, multiple lymphadenopathies, and polyposis
}

\author{
L. I. Fernández-Salazar, M. I. Jiménez-Cuenca ${ }^{1}$, H. Borrego-Pintado² ${ }^{2}$ B. Velayos-Jiménez \\ and J. M. González-Hernández
}

Services of Gastroenterology, ${ }^{\prime}$ Radiology and ${ }^{2}$ Pathology. Hospital Clínico Universitario de Valladolid. School of Medicine. Universidad de Valladolid. Spain

\section{CASE REPORT}

An 83-year-old male presented with anorexia, asthenia, weight loss, and profuse sweating. A 2-cm axillary lymphadenopathy and an abdominal mass in the right lower quadrant were palpable. Thoracic and abdominal CT scans were performed (Fig. 1). Colonoscopy revealed numerous sessile, erythematous polyps up to $1 \mathrm{~cm}$ in size with a white apex, and also pale, non-adenomatous polyps in the sigmoid and descending colon. Polyps in the transverse and right colon were less frequent. Polypoid masses prolapsed through the ileocecal valve. Figure 2 corresponds to an ileoscopy. Biopsy demonstrated colonic mucosal infiltration with proliferating monotonous small and medium-sized atypical lymphoid cells with irregular and cleaved nuclei, consistent with mantle lymphoma (Fig. 3). Immunohistochemistry was positive for CD20, CD43, bcl-2, CD79a, and CD5 stains. There was moderate expression of cyclin d1, but bcl-6, CD 10, kappa or lambda chains were not expressed. The patient received systemic R-CHOP chemotherapy.

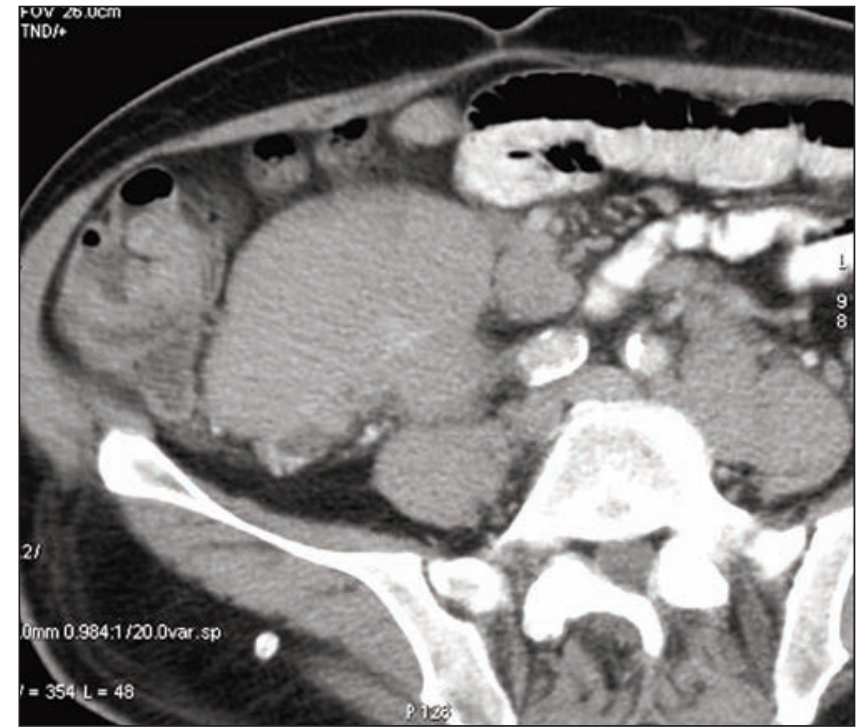

Fig. $1.12 \times 8 \times 9-\mathrm{cm}$ mass in the right iliac quadrant, and irregular thickened cecal mucosa. In higher CT sections lymphadenopathies are identified in the peritoneal and retroperitoneal celiac, and peri-renal areas.

Masa en fosa iliaca derecha de $12 \times 8 \times 9 \mathrm{~cm}$ y engrosamiento irregular de la mucosa de ciego. En cortes más altos se identifican adenopatías intra- $y$ retroperitoneales a la altura del tronco celiaco y de los hilios renales.

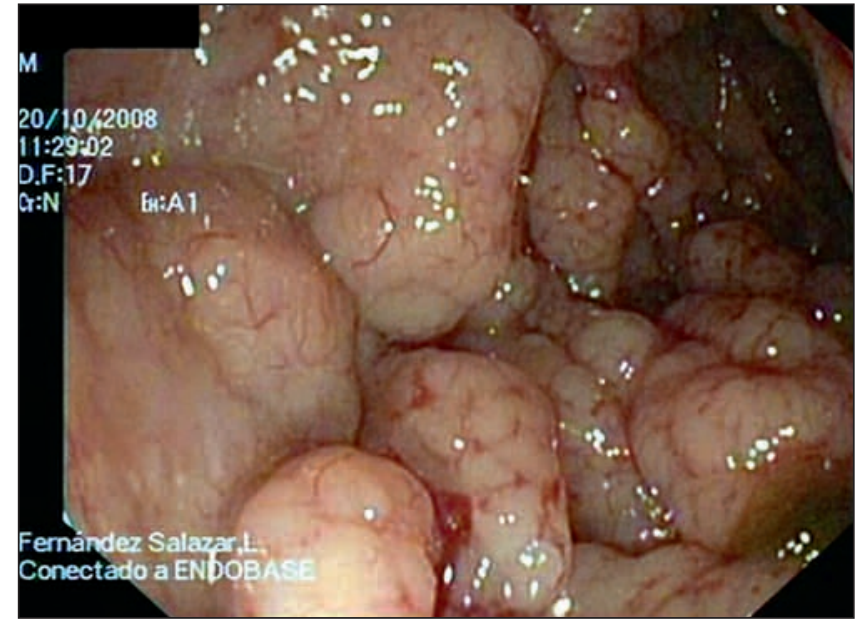

Fig. 2. Ileum: giant sessile polyps with cerebroid shape and increased vascular pattern.

Íleon: grandes formaciones polipoides de aspecto cerebroide y sésiles con aumento de la trama vascular capilar. 


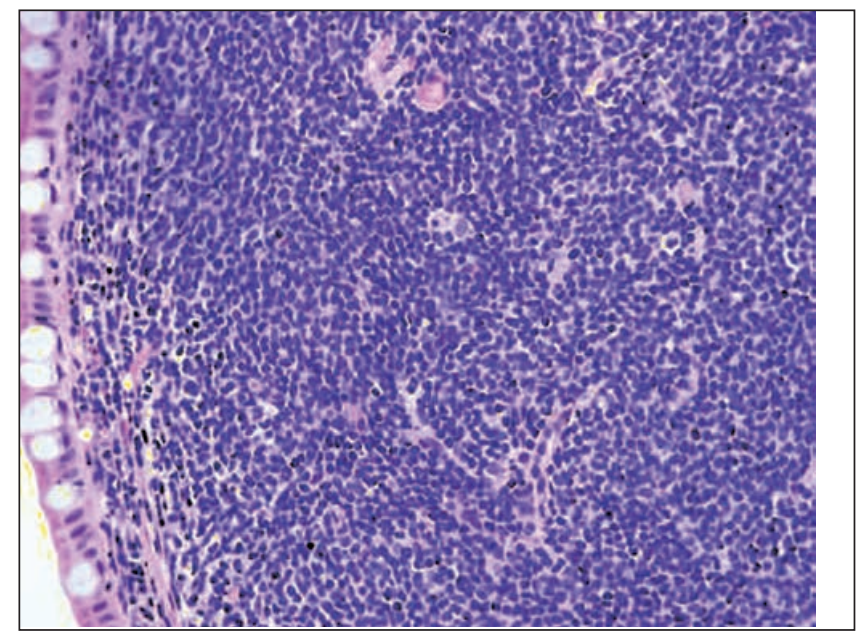

Fig. 3. Endoscopic colonic biopsy. HE40x. Mononuclear infiltrate beneath the colonic mucosa.

Biopsia de colon. HE40x. Infiltrado mononuclear por debajo de la mucosa colónica.

\section{DISCUSSION}

Most mantle lymphomas (ML) are diagnosed at advanced III or IV Ann Arbour stages, and are usually extranodal with bone marrow, liver or gastrointestinal extension. Lymphomatous polyposis is the endoscopic expression of ML and can extend from the esophagus to the rectum (1). Duodenal and colonic involvement is described as multiple sessile, flat, small, sometimes umbilicated polyps that can be enhanced with indigo carmine dye (1-3). Ileal involvement of ML can be similar to colonic disease (3) or consist of large or giant folds (2). Biopsies demonstrate atypical cleaved lymphoid cells expressing CD5 (lymphoid cell marker), CD10, CD 20, CD 22 (B-cell marker) and cyclin d1 (cell-cycle regulating protein) (1-4). Immunohistochemistry differentiates ML and folicullar lymphoma, which can also manifest as lymphomatous polyposis (5). ML has the poorest prognosis. Treatment is systemic chemotherapy (CHOP) combined with rituximab (anti-CD20). Radiotherapy can be used in some cases. Allogeneic bone marrow transplant may be the only long-term curative treatment (4).

\section{REFERENCES}

1. Christopoulos C, Stathakis S, Theodoropoulos I, Papavassiliou E, Savva S. Multiple lymphomatous polyposis. Br J Haematol 2004 ; 125 : 544.

2. Hokama A, Kishimoto K, Tomiyama R, Hirata T, Kinjo F, Fujita J. An unusual case of polyposis. Gut 2006; 55: 1574-91.

3. Wolfsen HC, Achem SR. Diffuse colonic polyposis detected at screening colonoscopy: mantle cell lymphoma. Endoscopy $2004 ; 36: 471$.

4. Lenz G, Dreyling M, Hiddenman W. Mantle cell lymphoma: established therapeutic options and future directions. Ann Hematol 2004; 83: 71-7.

5. Kodama T, Ohshima K, Nomura K, Taniwaki M, Nakamura N, Nakamura S, et al. Lymphomatous polyposis of the gastrointestinal tract, including mantle cell lymphoma, follicular lymphoma and mucosa-associatted limphoid tissue lymphoma. Histopathology 2005; 47: 467-78. 